\title{
OPTIMASI APLIKASI SIMAK-BMN UNTUK INVENTARISASI BARANG MILIK NEGARA BERBASIS APLIKASI MOBILE ANDROID
}

\author{
Ardian Prima Atmaja ${ }^{1}$, Fredy Susanto ${ }^{2}$ \\ 1,2 Jurusan Teknik, Politeknik Negeri Madiun \\ Email: ${ }^{1}$ atmaja@pnm.ac.id, ${ }^{2}$ fredy@pnm.ac.id
}

(Naskah masuk: 11 Mei 2019, diterima untuk diterbitkan: 08 Januari 2019)

\begin{abstract}
Abstrak
Dalam sebuah satuan kerja atau institusi pemerintah di Negara Republik Indonesia, terdapat barang-barang yang dibeli atau diperoleh atas beban APBN yang kemudian dapat diidentifikasikan sebagai bagian dari Barang Milik Negara (BMN). BMN tersebut dicatat dalam sebuah aplikasi bernama Sistem Informasi Manajemen dan Akuntansi Barang Milik Negara (SIMAK-BMN). Untuk melakukan monitoring BMN yang telah tercatat di aplikasi tersebut, Kuasa Pengguna Anggaran (KPA) dan tim monitoring seringkali menemui beberapa kesulitan. Hal ini diakibatkan dari keterbatasan aplikasi SIMAK-BMN yang belum sepenuhnya mudah dioperasikan untuk keperluan monitoring. Dengan kondisi seperti itu maka pada makalah ini dibahas pengembangan sistem informasi monitoring BMN terpadu dengan melakukan optimasi terhadap database SIMAK-BMN. Sistem yang dibangun dapat dijalankan oleh tim monitoring BMN secara online menggunakan internet. Selain itu, dikembangkan pula sistem monitoring BMN secara mobile yang dapat diinstall pada perangkat smartphone berbasis Android. Sehingga, dalam pengelolaaanya, petugas tim pencatat dan penginventaris BMN dapat menggunakan smartphone mereka untuk membantu memudahkan pekerjaaan inventarisasi dengan melakukan scanning QR Code dari tiap-tiap BMN. Dengan adanya sistem monitoring BMN yang merupakan optimasi dari database SIMAK-BMN tersebut, diharapkan dapat mempermudah fungsi monitoring BMN dan menjadi kontribusi dalam pengembangan sistem monitoring internal suatu satuan kerja di Republik Indonesia serta mendukung kebijakan-kebijakan pengelolaan BMN.
\end{abstract}

Kata kunci: sistem monitoring Barang Milik Negara, optimasi SIMAK-BMN, aplikasi BMN berbasis Android, scan $Q R$ Code $B M N$

\section{ANDROID MOBILE APPLICATION BASED OPTIMIZATION OF SIMAK-BMN APPLICATION FOR INVENTORY OF STATE GOODS}

\begin{abstract}
In a unit or institution in the government of State of the Republic of Indonesia, there are goods obtained at the expense of the APBN which can be identified as the State Goods (BMN). BMN is recorded in an application called the Management Information System and Accounting for State Goods (SIMAK-BMN). To monitor the BMNs that have been recorded in that application, the Budget User Authority (KPA) and the monitoring team often encounter some difficulties. This is due to the limitations of the SIMAK-BMN application which has not been fully operational for monitoring purposes. With such conditions, this study discusses about the development of integrated BMN monitoring information system by optimizing the SIMAK-BMN database. The built system can be run by the BMN monitoring team using the internet. Moreover, also developed a mobile BMN monitoring system that can be installed on Android-based smartphone devices. Thus, in it's management, BMN registration team can use their smartphone to scanning $Q R$ Code from each item of BMN. With the BMN monitoring system which is the optimization of the SIMAK-BMN database, it is expected to facilitate the BMN monitoring function and become a contribution in developing the internal monitoring system of a work unit in the government of Republic of Indonesia as well as supporting the policies of BMN management.
\end{abstract}

Keywords: monitoring system of State Goods, SIMAK-BMN optimization, Android-based BMN application, QR Code BMN scanning

\section{PENDAHULUAN}

Dalam suatu instansi negeri atau satuan kerja di seluruh wilayah Republik Indonesia, setiap tahun melakukan pengadaan barang maupun jasa yang bermanfaat dalam mendukung kinerja instansi tersebut. Pengadaan barang dan jasa tersebut dibiayai dari Anggaran Pendapatan Belanja Negara (APBN) ataupun Anggaran Pendapatan Belanja Daerah 
(APBD). Barang-barang yang dibeli atau diperoleh atas beban APBN tersebut dapat diidentifikasikan sebagai bagian dari Barang Milik Negara (BMN). Menurut Permenkeu No. 78/PMK.06/2014, Barang Milik Negara atau BMN merupakan barang-barang yang dibeli atau diperoleh atas beban Anggaran Pendapatan dan Belanja Negara atau berasal dari perolehan lain yang sah.

Perolehan aset lainnya yang sah menurut Peraturan Pemerintah Nomor 6 Tahun 2006 tentang Pengelolaan Barang Milik Negara/Daerah meliputi hibah atau sumbangan, pelaksanaan perjanjian atau kontrak, yang diperoleh berdasarkan ketentuan undang-undang, serta berdasarkan pada putusan pengadilan yang telah memperoleh kekuatan hukum tetap.

Sedangkan dalam Undang- undang Nomor 17 Tahun 2003 tentang Keuangan Negara disebutkan bahwa keuangan negara merupakan semua hak dan kewajiban negara yang dapat dinilai dengan uang dan segala sesuatu baik berupa uang maupun berupa barang yang dapat dijadikan milik negara berhubungan dengan pelaksanaan hak dan kewajiban tersebut. Adapun yang tidak termasuk dalam pengertian BMN yakni barang-barang yang dikuasai dan atau dimiliki oleh pihak-pihak di bawah ini, antara lain :

a. Pemerintah Daerah, dengan sumber dana yang berasal dari APBD termasuk sumber dana yang berasal dari APBN namun sudah diserahterimakan kepada Pemerintah Daerah.

b. Badan Usaha Milik Negara / Badan Usaha Milik Daerah, antara lain terdiri dari :

i. Perusahaan Perseroan

ii. Perusahaan Umum

c. Bank Pemerintah dan Lembaga Keuangan Milik Pemerintah.

Setiap BMN dilakukan pengklasifikasian dengan metode tertentu sehingga memberikan kemudahan dalam kegiatan pengelolaannya. Peraturan Menteri Keuangan (Permenkeu) Nomor 97/PMK.06/2007 tentang Penggolongan dan Kodefikasi Barang Milik Negara membagi BMN dalam beberapa klasifikasi golongan, bidang, kelompok, sub kelompok, dan subsub kelompok. Klasifikasi golongan menjadikan BMN global sedangkan klasifikasi sub-sub kelompok menjadikan BMN semakin rinci. Peraturan Menteri Keuangan RI nomor 246/PMK.06/2014 tentang Tata Cara Pelaksanaan Penggunaan Barang Milik Negara mengatur tentang tata cara pelaksanaan penggunaan Barang Milik Negara. Gambar 1 merupakan tampilan antarmuka login aplikasi SIMAK-BMN.

BMN yang selalu mengalami penambahan atau pengurangan nilai tersebut dicatat dalam sebuah aplikasi bernama Sistem Informasi Manajemen dan Akuntansi Barang Milik Negara (SIMAK-BMN). Aplikasi ini bersifat wajib untuk digunakan oleh instansi negara atau satuan kerja di seluruh Indonesia yang mengelola BMN. Aplikasi SIMAK-BMN terdiri dari antarmuka aplikasi yang berfungsi sebagai interface aplikasi dengan pengguna, dan database sebagai penyimpan data BMN.

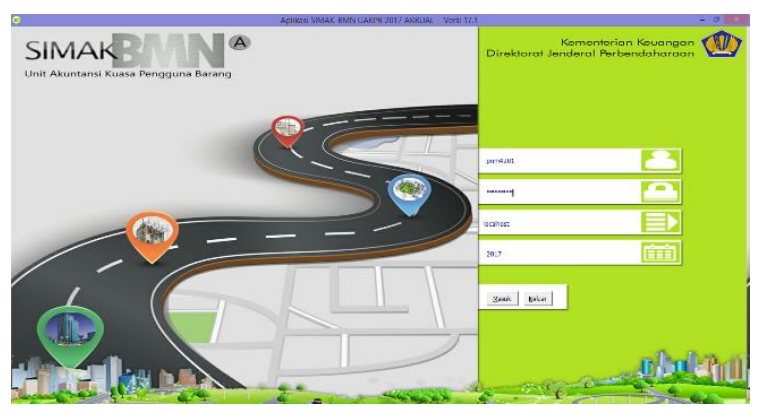

Gambar 1. Antarmuka aplikasi SIMAK-BMN (login) versi 17.1

Dalam mengelola BMN, sebuah satuan kerja memiliki seorang Kuasa Pengguna Anggaran (KPA). KPA adalah pejabat yang ditunjuk oleh Pengguna Barang atau kepala satuan kerja untuk menggunakan barang yang berada dalam penguasaannya dengan sebaik-baiknya. Seorang KPA bertanggung jawab penuh terhadap pengelolaan BMN yang ada di satuan kerja di bawahnya. Sehingga dalam pengelolaan BMN, seorang KPA berhak untuk melakukan monitoring terhadap BMN yang digunakannya. Seiring dengan berfungsinya aplikasi SIMAK-BMN, seringkali ditemui pula beberapa kesulitan dalam melakukan monitoring BMN yang telah tercatat di aplikasi tersebut. Kesulitan itu disebabkan oleh sifat aplikasi yang stand alone atau hanya untuk diinstal di sebuah komputer dan tidak bisa digunakan dalam sebuah jaringan. Hal ini mengakibatkan aplikasi SIMAK-BMN tidak memungkinkan untuk diakses secara jaringan. Atau dengan kata lain, aplikasi hanya bisa dioperasikan di komputer yang telah diinstalnya.

Pada penelitian Kartika (2013), mengangkat topik tentang peran serta pemanfaatan SIMAK-BMN dalam manajemen aset di Pengadilan Tinggi Agama Medan dari aspek teknis, operasi, dan perilaku ekonomis. Hasilnya adalah bahwa pelaksanaan dan pemanfaatan SIMAK-BMN memberikan kontribusi positif bagi organisasi namun tidak dijelaskan kekurangan aplikasi SIMAK-BMN dalam hal monitoring. Penelitian Kinantaka (2011) mengungkapkan bahwa tanggapan responden terhadap SIMAK-BMN secara keseluruhan sudah baik. Hanya saja pada indikator Languange, Akurasi, Presisi dan Auditabilitas sedikit belum sepenuhnya baik. Hal ini dikarenakan, dalam indikator Language adalah penyingkatan kalimat yang kurang tepat sehingga sedikit sulit diingat, dalam indikator Akurasi dan Presisi adalah persepsi tiap orang terhadap suatu jenis atau sub-kelompok barang berbeda sehingga pemasukan saat pemasukan data barang.

Penelitian Harisudin (2015) yang bertujuan untuk menganalisis efektivitas Sistem Informasi Manajemen dan Akuntansi Barang Milik Negara (SIMAK BMN) pada Fakultas Pertanian Universitas Sebelas Maret Surakarta (UNS) menyimpulkan 
bahwa pengoperasian aplikasi SIMAK-BMN sudah dilakukan dengan baik sehingga tercaapainya opini Wajar Tanpa Pengecualian (WTP) di Fakultas Pertanian UNS. Namun diperlukan kegiatan yang lebih tertib dalam administrasi pengelolaan Barang Milik Negara pada Fakultas Pertanian Universitas Sebelas Maret Surakarta yang meliputi pembukuan, inventarisasi sampai pelaporan Barang Milik Negara. Selain itu perlu update program SIMAK-BMN (SIMAK-BMN online) sehingga dapat mengikuti perkembangan dan kebutuhan dengan harapan kegiatan Administrasi Pengelolaan SIMAK-BMN lebih tertib, valid dan akurat.

Nasruddin (2015) dalam penelitiannya melihat bahwa aplikasi SIMAK-BMN telah berjalan dengan efektif dengan catatan pegawai yang ditempatkan sebagai operator sistem memiliki bekal pengetahuan yang memadai dalam mengoperasikan aplikasi SIMAK-BMN. Di sisi pelaporan ditemukan masih terjadi kesalahan meski jumlahnya tidak signifikan sehingga kualitas informasi pada laporan yang dihasilkan masih dianggap wajar. Hal tersebut terbukti dengan adanya kemajuan opini yang diberikan terhadap Laporan Keuangan Kementerian/Lembaga oleh Badan Pemeriksa Keuangan. Sedangkan penelitian Saptariani (2016) menemukan fenomena yang terjadi yakni ketidaksesuaian pada input data barang secara manual yang dimigrasikan ke dalam Sistem Informasi Manajemen Dan Akuntansi Barang Milik Negara (SIMAK-BMN), sehingga menyulitkan dalam pengelolaan Barang Milik Negara.

Beberapa kesulitan lainnya diantaranya dalam pencarian item BMN berdasarkan merk. Hal ini disebabkan karena di dalam SIMAK-BMN, data disimpan dan dicari berdasarkan jenis barang, bukan item barang dengan merk dan tipe barang itu sendiri. Kesulitan lainnya yakni dalam hal mencari lokasi BMN tersebut dipasang atau disimpan. Meskipun lokasi atau ruangan BMN dapat dicari menggunakan SIMAK-BMN, namun disadari masih kurang informatif bagi pengguna. Maka dengan adanya aplikasi SIMAK-BMN yang telah diatur penggunaannya untuk menyimpan dan mengelola data BMN di setiap satuan kerja tersebut, serta perlunya seorang KPA dan pengelola BMN dalam melakukan monitoring BMN, pada penelitian ini akan dioptimalkan pengelolaan SIMAK-BMN yang sudah ada untuk melakukan monitoring BMN melalui sebuah Sistem Informasi Manajemen (SIM). Pengembangan sistem informasi manajemen yang dibangun berbasis web dan Android mobile sehingga memungkinkan untuk diakses menggunakan internet, tidak hanya oleh operator BMN namun oleh petugas monitoring BMN di lap angan.

Sistem Informasi Manajemen (SIM) adalah sebuah sistem yang berbasis komputer yang membuat informasi tersedia bagi pengguna dengan kebutuhan yang serupa (Mcleod \& Schell, 2007). SIM melaporkan dan menulis ke perangkat lunak sehingga menghasilkan laporan baik laporan berkala maupun laporan khusus. Sebuah SIM dapat berfungsi dengan baik apabila semua proses didukung dengan teknologi yang sesuai, sumber daya yang berkualitas, dan komitmen organisasi atau institusi pengguna SIM tersebut. Manfaat dari SIM yakni untuk mendukung fungsi operasi, manajerial, dan pengambilan suatu keputusan dalam sebuah organisasi. Dengan demikian informasi yang dihasilkan harus berkualitas dan akan menentukan efektivitas pengambilan keputusan. Ada tiga pilar utama yang menentukan kualitas informasi yakni akurasi, ketepatan waktu dan relevansi (Kumorotomo, 1997).

Berdasarkan pada latar belakang yang diuraikan sebelumnya, maka dilakukan optimasi pengelolaan database SIMAK-BMN yang sudah ada dan dipakai oleh semua satuan kerja di seluruh Indonesia ke dalam sistem monitoring BMN berbasis web serta dikembangkan sebuah aplikasi berbasis Android yang dapat diinstal pada smartphone sehingga dapat memudahkan dan mempercepat petugas pencatat dan penginventaris BMN dalam menjalankan tugasnya. Selain itu, dengan adanya sistem yang saling terintegrasi tersebut, pihak Bagian Umum dan Kuasa Pengguna Anggaran dapat dengan mudah melakukan monitoring terhadap aset-aset BMN yang ada di satuan kerjanya.

\section{METODE}

Metode eksperimental dipilih untuk menjalankan penelitian ini. Gambar 2 menunjukkan alur pelaksanaan penelitian yang terdiri dari enam tahapan.

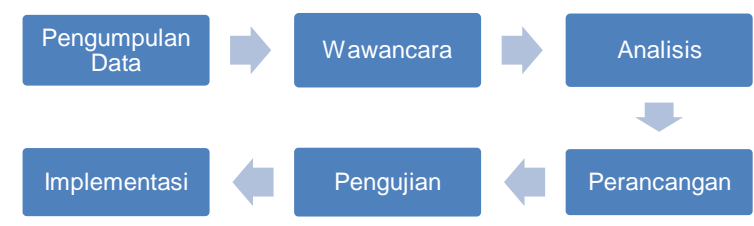

Gambar 2 Metode penelitian

Pada tahap awal, kegiatan pengumpulan data dilakukan untuk memperoleh referensi-referensi pendukung penelitian, yakni berupa undang-undang dan peraturan-peraturan Barang Milik Negara yang berlaku, buku-buku teks penunjang pemrograman web dan Android serta hasil penelitian serupa yang telah dilakukan oleh para peneliti lainnya. Setelah itu dilakukan wawancara untuk menggali informasi yang dimiliki oleh stakeholder, yakni operator SIMAKBMN dalam menggunakan aplikasi SIMAK-BMN, serta tim inventaris yang bertugas melakukan inventarisasi terhadap penyebaran dan kondisi asetaset BMN yang dalam hal ini terdapat di Politeknik Negeri Madiun. Wawancara juga akan menyimpulkan bagaimana rencana implementasi sistem monitoring Barang Milik Negara berbasis web yang telah dikembangkan ini serta bagaimana cara kerja BMN Mobile berbasis Android yang digunakan 
untuk melakukan inventaris dan monitoring menggunakan smartphone.

Hasil dari wawancara pertama ditemukan bahwa aplikasi SIMAK-BMN tidak bisa memaparkan data BMN secara informatif, terutama lokasi sebaran BMN yang telah diinventarisasi. Hal ini dikarenakan antarmuka kurang user friendly sehingga membingungkan pengguna yang akan melakukan monitoring BMN. Fitur pencarian BMN berdasarkan keyword juga tidak ditemukan sehingga akan sangat membingungkan pengguna bila akan melakukan pencarian terhadap suatu aset BMN. Selain itu, aplikasi SIMAK-BMN juga harus dijalankan pada komputer yang telah diinstal aplikasi SIMAK-BMN. Hal ini mengingat bahwa aplikasi tersebut bersifat stand alone. Sedangkan hasil wawancara kedua yakni dari petugas inventarisasi BMN, disimpulkan bahwa mereka tidak memiliki sistem informasi terpusat yang mampu menyimpan data hasil inventarisasi. Selama ini hanya digunakan aplikasi spreadsheet yang dijalankan oleh masingmasing petugas inventaris untuk melakukan pendataan inventarisasi sehingga sangat berpotensi terjadinya data yang berulang bahkan hilang.

Pada tahap analisis, dilakukan analisis terhadap permasalahan awal yang ditemukan pada domain permasalahan yaitu pada aplikasi SIMAK-BMN. Tahapan ini memahami aturan bisnis dan tabel-tabel pada database yang telah ada serta menentukan arah optimasinya. Sistem ini dikembangkan dengan metode pengembangan perangkat lunak Rapid Aplication Development (RAD). RAD merupakan sebuah model proses pengembangan perangkat lunak yang menekankan pada siklus pengembangan yang sangat pendek (Pressman, 1997). Noertjahyana (2002) menambahkan bahwa Rapid Application Development (RAD) merupakan proses pengembangan software incremental, yang menekankan pada siklus pengembangan yang sangat pendek. Untuk proses pengembangan suatu sistem informasi yang normal membutuhkan waktu minimal 180 hari, akan tetapi dengan menggunakan metode RAD suatu sistem dapat diselesaikan hanya dalam waktu 30-90 hari. Siklus waktu pengembangan yang pendek sangat diperlukan mengingat sistem ini terintegrasi dengan sistem dan database lain sehingga dapat mempersingkat waktu idle proses-proses lainnya yang berhubungan dengan pengembangan sistem ini. Penelitian Martin dan Tanaamah (2018) membangun sebuah website sebagai media promosi untuk toko yang dikembangkan melalui metode RAD (Rapid Application Development) yang diproses melalui 3 tahapan, yaitu perencanaan, workshop untuk perancangan dan pembuatan prototype, dan implementasi apakah fungsi dari website tersebut sudah berjalan dengan baik dan siap digunakan.

Proses RAD menekankan pada pemakaian kembali (reuse) yang memungkinkan berkurangnya keseluruhan waktu pengujian, namun komponen harus diuji dan harus dilatih secara penuh serta terintegrasi. Pengujian terhadap perangkat lunak atau sistem informasi yang telah dibangun bertujuan untuk memastikan bahwa sistem informasi yang dibangun telah sesuai dengan spesifikasi yang dituangkan di dalam fase-fase sebelumnya. Dalam pengembangan sistem sesuai pendekatan RAD, diambil beberapa fase antara lain pemodelan bisnis, pemodelan data, pemodelan proses, pemodelan kerangka laman dan pemrograman, serta pengujian.

\subsection{Pemodelan Bisnis}

Pemodelan bisnis pada sistem ini ditunjukkan pada Gambar 3, dimana terlibat empat pihak yang mengelola sistem ini mulai dari tim inventaris sebagai petugas inventarisasi $\mathrm{BMN}$ di lapangan, hingga informasi inventarisasi kepada sub bagian umum dan pimpinan. Data yang diinput oleh tim inventaris di lapangan dengan cara scanning barang-barang aset melalui $Q R$ Code merupakan data terbaru BMN yang berasal dari aplikasi SIMAK BMN. Hasil scanning akan terlebih dahulu diverifikasi oleh operator SIMAK-BMN sesuai data SIMAK BMN yang telah diimpor sebelumnya. Setelah hasil inventarisasi dinyatakan valid, dimana data BMN sesuai dengan data pada SIMAK BMN, maka informasi hasil inventarisasi tersebut disampaikan ke atasan yakni Kepala Sub Bagian Umum serta kepada pimpinan intitusi.

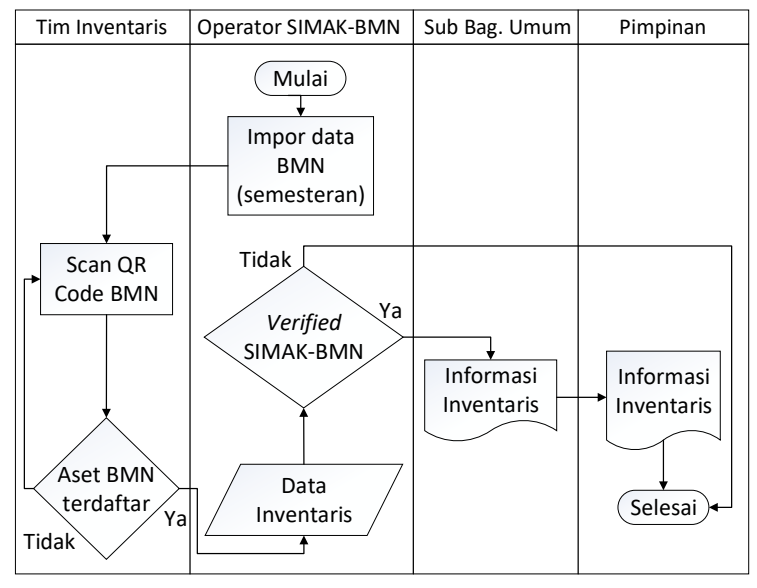

Gambar 3. Flowmap aliran bisnis sistem

\subsection{Pemodelan Data}

Gambar 4 merupakan model relasi antar entitas/tabel pada database sistem dimana terdapat sebuah relasi yang menghubungkan tabel gedung dengan tabel ruang, dan tabel inventaris dengan tabel foto. Terlihat bahwa tabel t_mapbrg dan t_masteru tidak direlasikan kerena kedua tabel tersebut berasal dari database SIMAK BMN yang telah diimpor. Sedangkan tabel simakbmn berfungsi untuk merekam data histori periodisasi update impor database dari SIMAK BMN. 


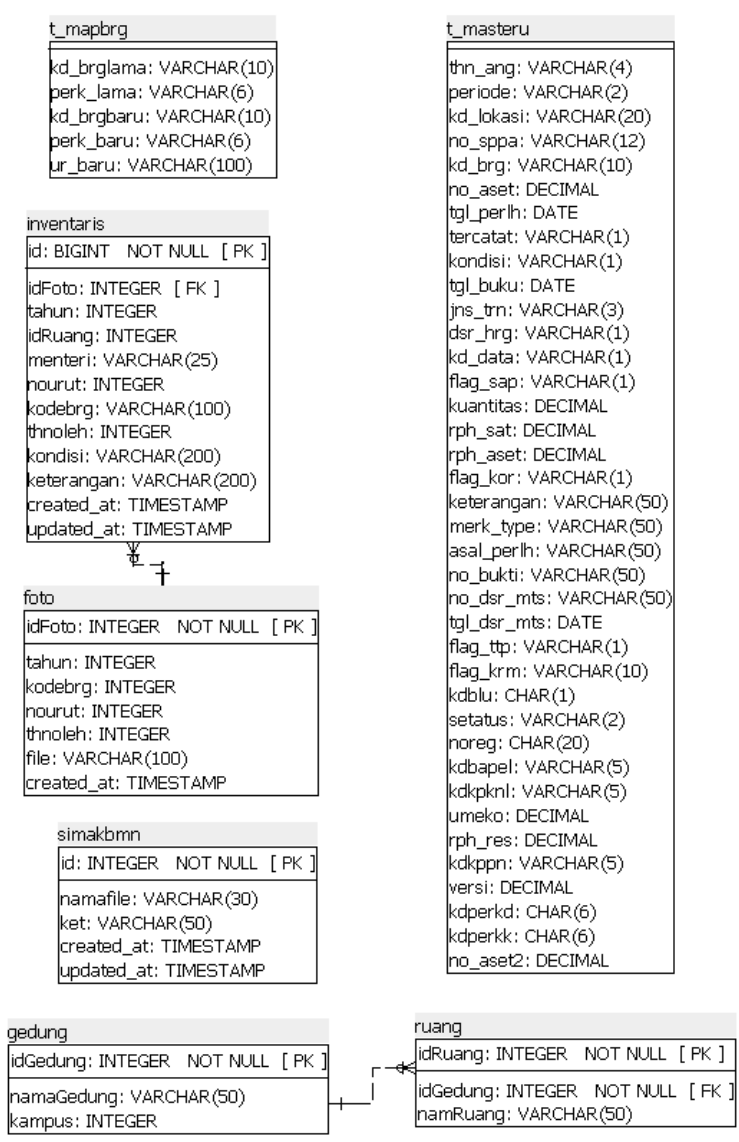

Gambar 4. Pemodelan Data

\subsection{Pemodelan Proses}

Secara umum, alur sistem yang diimplementasikan ditunjukkan pada Gambar 5, dimana data BMN awal berasal dari impor database SIMAK-BMN yang terinstal secara stand alone pada komputer operator BMN. File-file yang diimpor yakni t_mapbrg.MYD, $\quad t$ mapbrg.MYI, $t$ mapbrg.frm, dan $t$ masteru.frm. Keempat file database tersebut diimpor ke aplikasi Sistem Informasi Monitoring BMN yang disimpan di server. Server yang telah online pada URL http://imonev.pnm.ac.id dan dapat diakses menggunakan perangkat-perangkat yang dapat terkoneksi dengan internet, termasuk smartphone. Smartphone yang telah terinstal aplikasi BMN Mobile dan terdaftar menjadi petugas inventarisasi BMN dapat melakukan scanning aset-aset BMN yang telah ditempeli $Q R$ Code. Data hasil scanning inventarisasi langsung terkirim ke server BMN sehingga dapat langsung dimonitor dan diverifikasi oleh petugas monitoring. Hasil verifikasi kemudian diteruskan ke kepala Sub Bagian Umum dan pimpinan.

Kode barang yang di-generate menjadi QR Code tersusun dari kode barang, nomor urut barang, dan tahun perolehan. Kode barang merupakan urutan kode yang telah dibuat (kodefikasi) melalui aplikasi SIMAK BMN yang terdiri dari kode golongan, bidang, kelompok, sub kelompok, dan sub-sub kelompok barang. Aturan kodefikasi BMN sesuai dengan Permenkeu No. 29 tentang Penggolongan dan penjelasan format kode QR Code tersebut antara lain:

$$
\begin{aligned}
& \mathrm{a} \cdot \mathrm{bc} \cdot \mathrm{de} \cdot \mathrm{fg} \cdot \mathrm{hij-klm-nopq} \\
& \mathrm{a}=\text { kode golongan barang } \\
& \mathrm{bc}=\text { kode bidang barang } \\
& \mathrm{de}=\text { kode kelompok barang } \\
& \mathrm{fg}=\text { kode sub belompok barang } \\
& \mathrm{h} i \mathrm{j}=\text { kode sub-sub kelompok barang } \\
& \mathrm{klm}=\text { nomor urut kelompok barang } \\
& \text { nopq }=\text { tahun perolehan }
\end{aligned}
$$

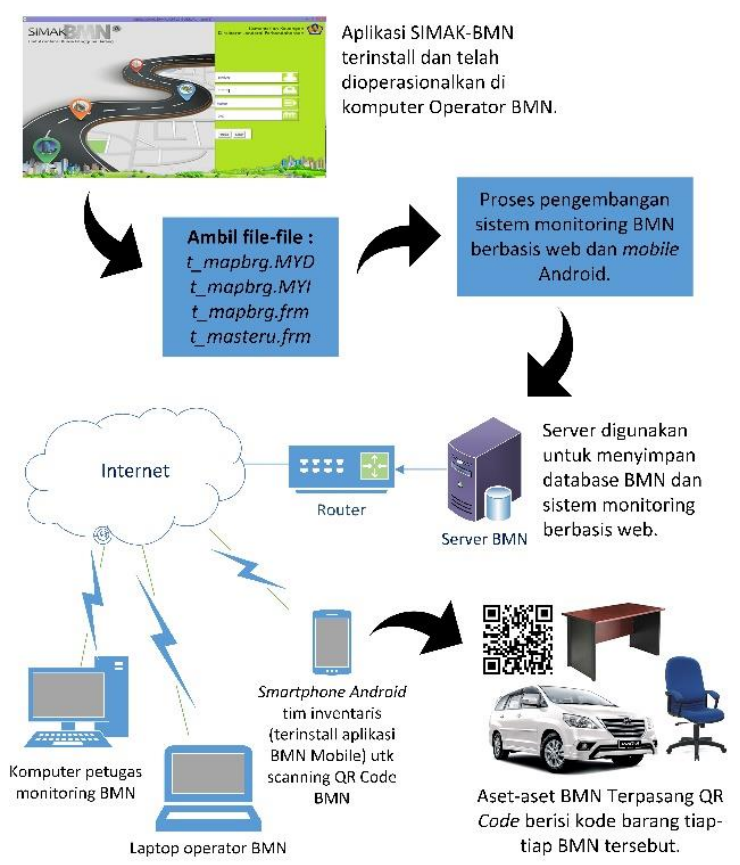

Gambar 5. Diagram Alur Sistem

\subsection{Pemodelan Aplikasi}

Pemodelan aplikasi terdiri dari pemodelan kerangka laman dan pemrograman. Pemodelan kerangka laman dibagi menjadi dua, yakni laman web sebagai pengolahan data dan laman pada aplikasi android. Pada laman berbasis web, kerangka laman terdiri dari dua bagian utama yakni bagian statis yang terdiri dari header, menu, dan footer. Bagian statis ini cenderung tetap, yakni menu-menu utama antara lain; Data BMN, Hasil Inventaris, BMN Sudah Dihapus, Gedung \& Ruangan, dan Setting. Sedangkan laman dinamis berisi konten dinamis laman itu sendiri. Gambar 6 menunjukkan kerangka laman web dan Gambar 7 merupakan kerangka laman aplikasi android. Sedangkan untuk pemrograman web, digunakan framework PHP Laravel 5.1 dan App Inventor untuk membangun aplikasi inventarisasi \& monitoring BMN berbasis Android. Aplikasi tersebut diberi nama BMN Mobile.

App Inventor adalah tool pemrograman yang menggunakan metode perograman blok untuk 
membangun sebuah aplikasi berbasis mobile yang nantinya diinstal pada sebuah smartphone. App Inventor merupakan alat untuk membangun aplikasi di platform Android secara visual dan menentukan perilaku aplikasi dengan menggabungkan blok seperti puzzle (Wolber, dkk., 2015). Pengembang dapat membangun aplikasi-aplikasi berbasis Android menggunakan App Inventor, antara lain; game, software edukasi, penunjuk lokasi, pemindai barcode/QR code, asisten digital, pemutar lagu, aplikasi SMS, aplikasi pengontrol robot, aplikasi kompleks seperti pengelola informasi, dan dapat berkomunikasi dengan website.

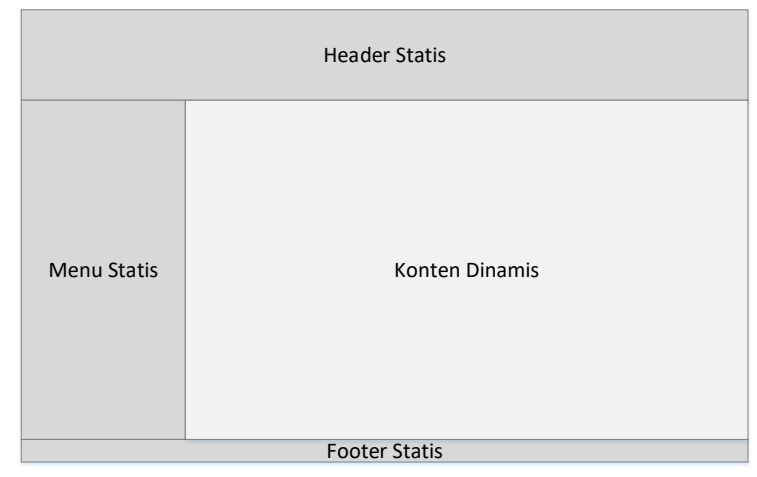

Gambar 6. Kerangka Laman Web
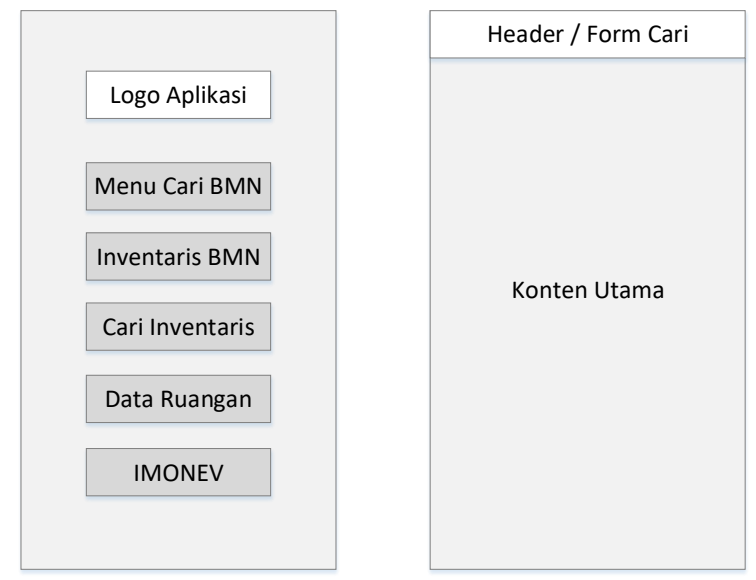

Gambar 7. Kerangka Aplikasi Berbasis Android

Pada penelitian Vazquez-Briseno, dkk., (2012) dijelaskan penggunaan smartphone untuk menghubungkan benda fisik dengan dunia digital dengan menggunakan teknik AIDC dan dijelaskan pula pemanfaatan $Q R$ Code dan teknologi RFID/NFC serta API yang dibutuhkan untuk menerapkan aplikasi mobile yang memanfaatkan $Q R$ Code tersebut. Beberapa proyek aplikasi $Q R$ Code yang dijelaskan pada penelitian ini menunjukkan pemanfaatannya yang besar sekali di berbagai bidang. Proyek-proyek tersebut berdampak pada bidangbidang penting dalam kehidupan kita seperti pendidikan, kesehatan, perdagangan dan lain-lain.

Dengan meningkatnya jumlah smartphone yang memiliki kemampuan NFC dan kamera yang tersedia di pasaran, akan menjadi alat penting untuk membantu pekerjaan manusia di kehidupan sehari- hari. Interaksi antara pengguna dan fungsi yang ada pada sistem dideskripsikan pada diagram use case yang ditunjukkan oleh Gambar 8.

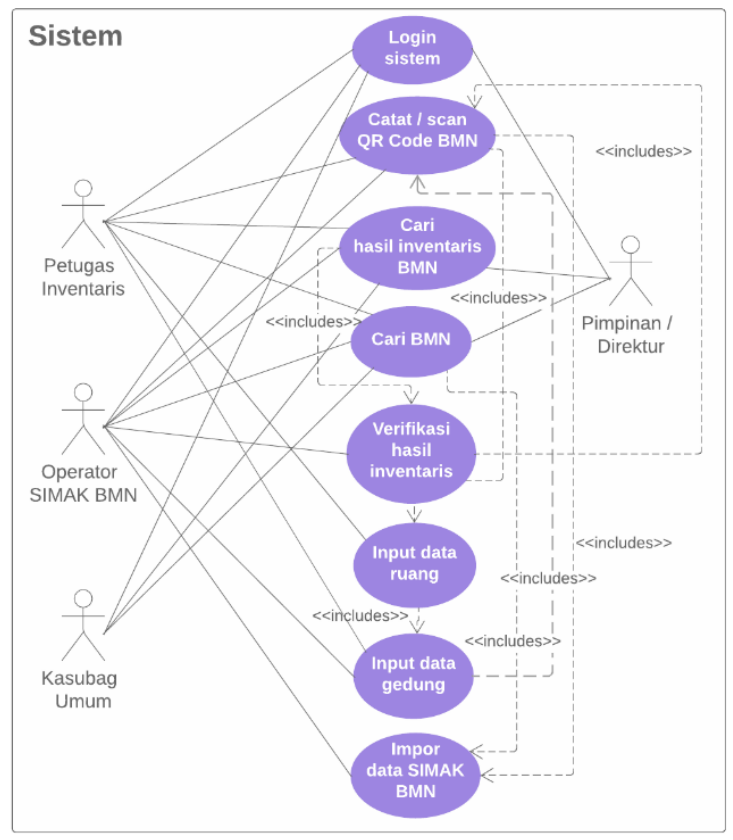

Gambar 8. Diagram Use Case

\subsection{Pengujian}

Setelah dilakukan desain terhadap perangkat lunak, maka dilakukan pengujian (testing and turnover). Pengujian dilakukan dengan terlebih dahulu merancang jaringan yang menghubungkan aplikasi BMN Mobile pada smartphone Android dengan komputer server menggunakan internet. Gambar 9 menunjukkan rancangan jaringan untuk mendukung sistem yang telah dibangun.

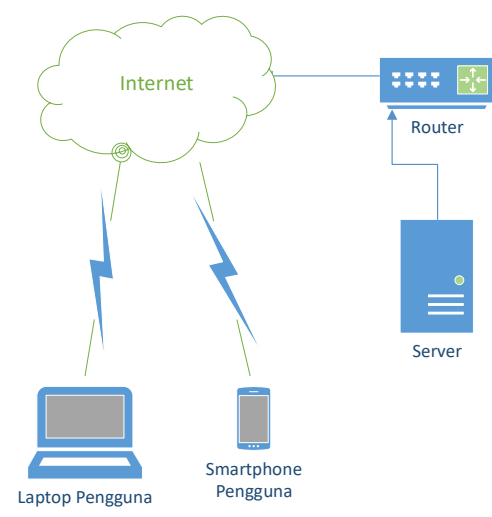

Gambar 9. Rancangan Jaringan

Tahap pengujian dilakukan dalam dua metode, yakni Black Box dan White Box. Metode pengujian Black Box berfokus terhadap persyaratan fungsional perangkat lunak. Pengujian ini cenderung memperhatikan struktur kontrol dan berfokus pada domain informasi yakni data BMN dan inventarisasi. Pengujian Black Box dilakukan hanya dengan 
mengamati hasil eksekusi melalui data uji dan memeriksa fungsional dari perangkat lunak. Penguji hanya bisa melihat penampilan dan fungsinya saja, tanpa tahu bagaimana proses di dalamnya.

Sedangkan pengujian White Box menggunakan struktur kontrol desain prosedural untuk memperoleh test case. Metode ini didasarkan pada pengamatan yang teliti terhadap detail prosedural sebuah aplikasi tanpa memperhatikan kode-kode yang digunakan untuk membangun perangkat lunak tersebut. Pengujian didasarkan pada pengecekan terhadap detail perancangan sistem, menggunakan struktur kontrol dari desain program secara prosedural untuk membagi pengujian ke dalam beberapa kasus pengujian. Sebelum melakukan pengujian, pada metode pengujian White Box dilakukan pendefinisian semua alur logika, dan pembuatan kasus-kasus untuk digunakan dalam pengujian.

\section{HASIL DAN PEMBAHASAN}

Seperti yang telah dibahas pada subab-subab sebelumnya, bahwa sistem yang dibangun terbagi menjadi dua yakni sistem berbasis web yang merupakan Sistem Informasi Monitoring dan sistem berbasis mobile (Android) yang diakses menggunakan smartphone. Kedua metode penggunaan tersebut hanya dapat diakses secara privat sehingga hanya petugas yang bertugas sebagai pengelola BMN saja yang dapat mengaksesnya. Langkah pertama sebelum melakukan pengelolaan terhadap data BMN dan inventaris, adalah melakukan pengesetan (setting) terhadap aplikasi monitoring BMN. Setting pertama yang dilakukan adalah melakukan update BMN yang berasal dari aplikasi SIMAK-BMN. Gambar 10 menunjukkan laman hasil inventarisasi $\mathrm{BMN}$ yang diperoleh dengan cara melakukan scan $Q R$ Code terhadap aset-aset BMN yang tersebar di lokasi masing-masing.

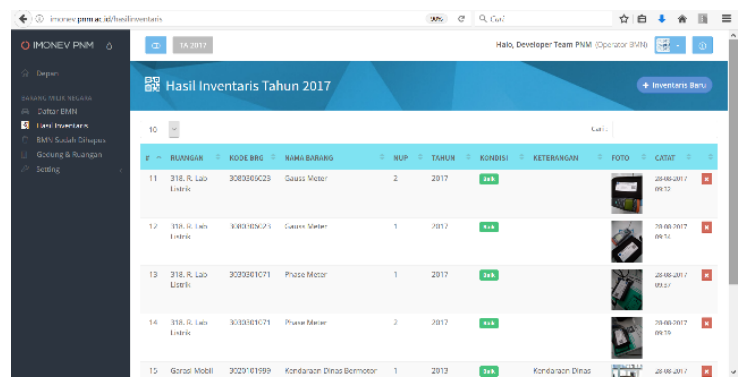

Gambar 10. Laman hasil inventarisasi BMN berbasis web

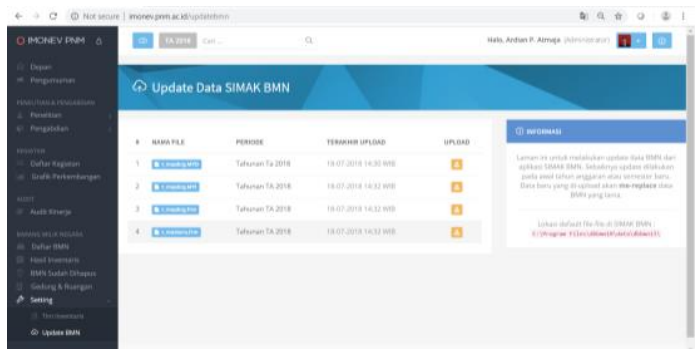

\section{Gambar 11. Laman setting sistem}

Gambar 11 menunjukkan laman untuk melakukan pengaturan (setting) terhadap sistem. Pada laman ini, file-file database yang didapat dari aplikasi SIMAK BMN diimpor ke dalam sistem yang dibangun setiap akhir periode pencatatan BMN yakni satu semester. Data ini nantinya digunakan sebagai dasar inventarisasi dan monitoring BMN. Sedangkan untuk aplikasi BMN berbasis mobile yang diinstal di smartphone Android, hanya pengguna tertentu yang telah ditetapkan sebelumnya yang diizinkan untuk mengakses aplikasi BMN Mobile. Sehingga pengguna yang memiliki wewenang sebagai petugas atau tim inventarisasi yang dapat melakukan tugasnya disini. Gambar 12 menunjukkan aktivitas inventarisasi BMN. Pada gambar tersebut, terlihat seorang petugas inventarisasi sedang melakukan scanning terhadap sebuah aset BMN melalui stiker $Q R$ Code yang tertempel. $Q R$ Code tersebut berisi kode aset dari aset tersebut di database SIMAKBMN. Sedangkan Gambar 13 menunjukkan antarmuka menu aplikasi BMN Mobile yang dapat diakses oleh petugas untuk melakukan scanning inventarisasi dan pengelolaan BMN pada aplikasi BMN Mobile setelah user berhasil melakukan login.

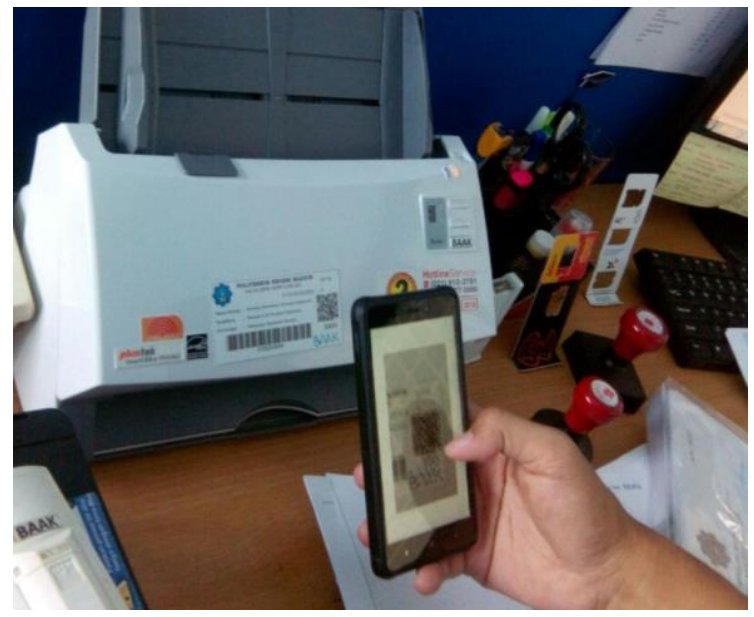

Gambar 12. Aktifitas scanning inventaris

Aplikasi akan melakukan scanning data kode barang melalui $Q R$ Code. Dalam kasus $Q R$ Code tidak terbaca karena rusak atau kotor, maka petugas dapat menginput kode barang secara manual. Foto barang yang di-scan dapat diambil secara langsung maupun tidak langsung (tersimpan di galeri). Lalu petugas memilih kondisi barang dan mengisi keterangan lain bila diperlukan. Setelah dilakukan pencatatan, maka data hasil scanning inventarisasi tersebut langsung disimpan di server menggunakan jaringan internet. Secara real time, pengelola BMN lainnya dapat menerima informasi hasil inventarisasi tersebut melalui suatu laman web yang dapat diakses melalui URL http://imonev.pnm.ac.id.

Gambar 14 menunjukkan detail hasil pencarian terhadap suatu aset BMN, yakni kendaraan dinas. Pada laman tersebut ditunjukkan pula data lengkap 
yang tercatat di database. Sedangkan Gambar 15 merupakan laman untuk melakukan scanning inventarisasi BMN. Pada laman tersebut petugas dapat mencatat aset-aset BMN yang ada dengan cara memindai (scanning) QR Code yang ada pada setiap aset BMN serta menambahkan kondisi aset dan keterangan bila diperlukan. Barang yang telah dicatat dapat dilihat oleh petugas melalui sistem informasi IMONEV untuk dilakukan verifikasi dan monitoring lebih lanjut.

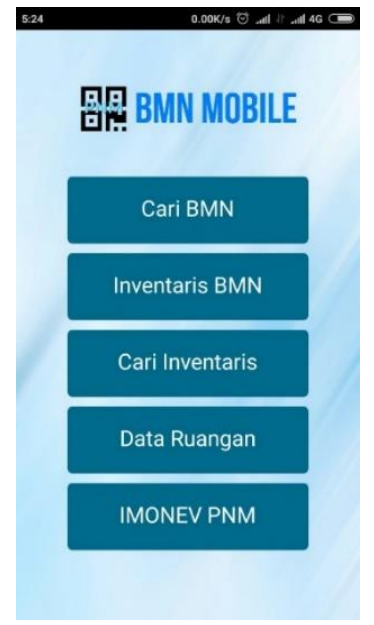

Gambar 13. Laman menu utama BMN Mobile
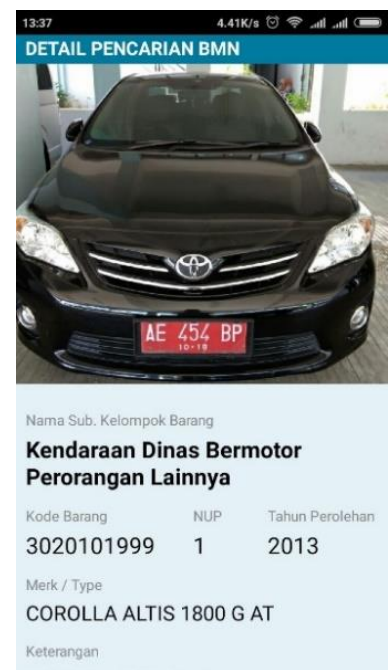

Gambar 14. Laman detail pencarian BMN

Hasil pengujian (black box) pada aplikasi BMN Mobile ditunjukkan pada Tabel 1. Sedangkan pada Tabel 2 ditampilkan hasil pengujian pada sistem informasi monitoring inventarisasi BMN berbasis web yang dapat diakses pada URL http://imonev.pnm.ac.id.

\section{KESIMPULAN}

Aplikasi SIMAK-BMN yang bersifat stand alone telah berhasil dilakukan optimasi, yakni dengan mengembangkannya menjadi sistem monitoring BMN terpadu yang terdiri dari sistem berbasis web dengan URL http://imonev.pnm.ac.id dan aplikasi BMN mobile berbasis Android sehingga dapat

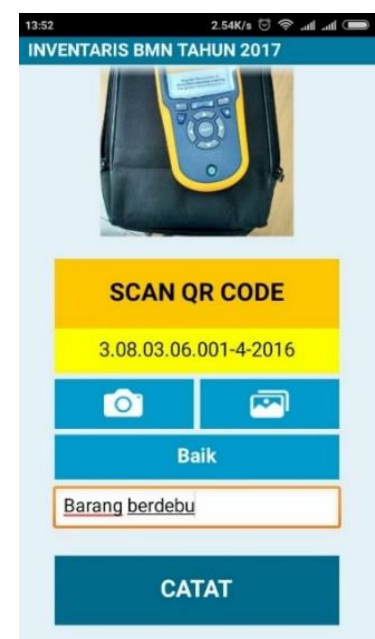

Gambar 15. Laman scanning inventarisasi BMN

Tabel 1. Hasil Pengujian Aplikasi BMN Mobile

\begin{tabular}{|c|c|c|c|}
\hline No & Pengujian & OK & Penjelasan \\
\hline 1 & Login aplikasi & $\sqrt{ }$ & Login app sesuai hak akses \\
\hline 2 & Cari inventaris & $\sqrt{ }$ & $\begin{array}{l}\text { Mencari hasil inventarisasi } \\
\text { berdasarkan keyword kode } \\
\text { barang, merk, atau type }\end{array}$ \\
\hline 3 & $\begin{array}{l}\text { View detail hasil } \\
\text { cari inventaris }\end{array}$ & $\sqrt{ }$ & $\begin{array}{l}\text { Tampilkan informasi detail } \\
\text { hasil cari inventaris }\end{array}$ \\
\hline 4 & Cari BMN & $\sqrt{ }$ & $\begin{array}{l}\text { Mencari data BMN } \\
\text { berdasarkan keyword kode } \\
\text { barang, merk, atau type }\end{array}$ \\
\hline 5 & View detail BMN & $\sqrt{ }$ & $\begin{array}{l}\text { Tampilkan informasi detail } \\
\text { hasil cari BMN }\end{array}$ \\
\hline 6 & View data gedung & $\sqrt{ }$ & Tampilkan data gedung \\
\hline 7 & Input data gedung & $\sqrt{ }$ & Input data gedung baru \\
\hline 8 & View data ruangan & $\sqrt{ }$ & Tampilkan data ruangan \\
\hline 9 & Input data ruangan & $\sqrt{ }$ & Input data ruangan baru \\
\hline 10 & $\begin{array}{l}\text { Menuju aplikasi } \\
\text { IMONEV }\end{array}$ & $\sqrt{ }$ & $\begin{array}{l}\text { Membuka laman web } \\
\text { http://imonev.pnm.ac.id }\end{array}$ \\
\hline
\end{tabular}

Tabel 2. Hasil Pengujian Aplikasi BMN Mobile

\begin{tabular}{|c|c|c|c|}
\hline No & Pengujian & OK & Penjelasan \\
\hline 1 & Login sistem informasi & $\sqrt{ }$ & $\begin{array}{l}\text { Login web sesuai hak akses } \\
\text { yang didapatkan }\end{array}$ \\
\hline 2 & $\begin{array}{l}\text { View data BMN per } \\
\text { tahun perolehan }\end{array}$ & $\sqrt{ }$ & $\begin{array}{l}\text { Tampilkan data BMN } \\
\text { berdasarkan tahun perolehan } \\
\text { tertentu }\end{array}$ \\
\hline 3 & $\begin{array}{l}\text { View data BMN per } \\
\text { lokasi inventarisasi }\end{array}$ & $\sqrt{ }$ & $\begin{array}{l}\text { Tampilkan data BMN } \\
\text { berdasarkan lokasi pada saat } \\
\text { dilakukan inventarisasi }\end{array}$ \\
\hline 4 & $\begin{array}{l}\text { View hasil } \\
\text { inventarisasi tahun } \\
\text { berjalan }\end{array}$ & $\sqrt{ }$ & $\begin{array}{l}\text { Tampilkan data BMN yang } \\
\text { telah diinventarisasi }\end{array}$ \\
\hline 5 & View BMN terhapus & $\sqrt{ }$ & $\begin{array}{l}\text { Tampilkan data BMN yang } \\
\text { telah dihapus dari SIMAK } \\
\text { BMN }\end{array}$ \\
\hline 6 & View data gedung & $\sqrt{ }$ & Tampilkan data gedung \\
\hline 7 & $\begin{array}{l}\text { Input, edit, delete data } \\
\text { gedung }\end{array}$ & $\sqrt{ }$ & Pengelolaan data gedung baru \\
\hline 8 & View data ruangan & $\sqrt{ }$ & Tampilkan data ruangan \\
\hline 9 & $\begin{array}{l}\text { Input, edit, delete data } \\
\text { ruangan }\end{array}$ & $\sqrt{ }$ & Pengelolaan data ruangan \\
\hline 10 & $\begin{array}{l}\text { Input, edit, delete } \\
\text { anggota tim inventaris }\end{array}$ & $\sqrt{ }$ & $\begin{array}{l}\text { Pengelolaan user yang dapat } \\
\text { menggunakan aplikasi BMN } \\
\text { Mobile }\end{array}$ \\
\hline 11 & $\begin{array}{l}\text { Upload/impor file } \\
\text { SIMAK BMN }\end{array}$ & $\sqrt{ }$ & $\begin{array}{l}\text { Updating data BMN } \\
\text { berdasarkan database SIMAK } \\
\text { BMN terbaru }\end{array}$ \\
\hline
\end{tabular}

membantu tim inventaris dalam melakukan kegiatan inventarisasi menjadi lebih mudah, cepat dan akurat. Pengguna pada sistem ini memiliki jenis yang beragam dimana masing-masing memiliki hak akses yang berbeda dalam mengakses sistem. 
Operator BMN dapat melakukan pengelolaan terhadap anggota-anggota tim inventaris dan setiap anggota tim inventaris dapat mengakses aplikasi BMN mobile untuk melakukan scanning inventarisasi terhadap aset-aset BMN. Aset BMN yang dilakukan scanning menggunakan aplikasi BMN Mobile langsung terkirim ke server sehingga para pihak terkait dapat langsung melakukan monitoring terhadap hasil inventarisasi secara real time.

\section{DAFTAR PUSTAKA}

HARISUDIN. 2015. Efektivitas Sistem Informasi Manajemen Dan Akuntansi Barang Milik Negara (SIMAK BMN) Di Fakultas Pertanian Universitas Sebelas Maret Surakarta tahun 2014. Jurusan Ilmu Administrasi Negara. Surakarta: Universitas Sebelas Maret.

KARTIKA, E. N. 2013. Peran dan Manfaat Sistem Informasi Manajemen dan Akuntansi Barang Milik Negara (SIMAK-BMN) dalam Pengelolaan Aset di Pengadilan Tinggi Agama Medan. Medan: Fakultas Ekonomi, Universitas Sumatera Utara.

KINANTAKA, F. F. 2011. Implementasi Kualitas Sofware Sistem Informasi Manajemen dan Akuntansi Barang Milik Negara (SIMAKBMN) Dampaknya Terhadap Kinerja Pegawai di Pusat Penelitian dan Pengembangan Sumber Daya Air (PUSLITBANG-SDA) Jawa Barat. Bandung: Universitas Komputer Indonesia.

KUMOROTOMO, W. 1997. Sistem Informasi Manajemen Dalam Organisasi Publik. Yogyakarta: Gadjah Mada Press.

MARTIN, J. dan TANAAMAH, A. R. 2018. Perancangan dan Implementasi Sistem Informasi Penjualan Berbasis Desktop Website Menggunakan Framework Bootstrap dengan Metode Rapid Application Development, Studi Kasus Toko Peralatan Bayi 'Eeng Baby Shop'. Jurnal Teknologi Informasi dan Ilmu Komputer (JTIIK). Malang: Fakultas Ilmu Komputer, Universitas Brawijaya.

MCLEOD, R. dan SCHELL, G. P. 2007. Management Information Systems Tenth Edition. Delhi: Pearson Education.

NASRUDIN, E. 2015. Efektivitas Sistem Informasi Manajemen dan Akuntansi Barang Milik Negara (SIMAK-BMN) Terhadap Pengelolaan Aset Negara. Jember: Jurnal Akuntansi Universitas Jember, 13(2).

NOERTJAHYANA, A. 2002. Studi Analisis RAD Sebagai Salah Satu Alternatif Metode Pengembangan Perangkat Lunak. Jakarta: Universitas Kristen Petra.
Peraturan Menteri Keuangan No. 29/PMK.06/2010 tentang Penggolongan dan Kodefikasi Barang Milik Negara. Jakarta: Kementerian Keuangan Republik Indonesia.

Peraturan Menteri Keuangan No. 78/PMK.06/2014 tentang Tata Cara Pelaksanaan Pemanfaatan Barang Milik Negara. Jakarta: Kementerian Keuangan Republik Indonesia.

Peraturan Menteri Keuangan No. 246/PMK.06/2014 tentang Tata Cara Pelaksanaan Penggunaan Barang Milik Negara. Jakarta: Kementerian Keuangan Republik Indonesia.

Peraturan Pemerintah No. 71 Tahun 2010 tentang Standar Akuntansi Pemerintah. Jakarta: Kementerian Sekretariat Negara Republik Indonesia.

PRESSMAN, R. S. 1997. Software Engineering: A Practitioner's Approach. New York: The McGraw-Hill Companies, Inc.

SAPTARANI, A. R. 2016. Tinjauan Atas Sistem Informasi Akuntansi Barang Milik Negara pada Pusat Penelitian dan Pengembangan Teknologi Mineral dan Batubara Bandung. Bandung: Universitas Komputer Indonesia.

Tim PPAKP. 2008. Modul Sistem Informasi dan Manajemen Akuntansi Barang Milik Negara (SIMAK-BMN). Jakarta: PPAKP.

Undang-undang Nomor 17 Tahun 2003 Tentang Keuangan Negara. Jakarta: Kementerian Sekretariat Negara Republik Indonesia.

VAZQUEZ-BRISENO, M., HIRATA, F. I., DE DIOS SANCHEZ-LOPEZ, J., JIMENEZGARCIA, E., NAVARRO-COTA, C., \& NIETO-HIPOLITO, J. I. 2012. Using RFID/NFC and QR-code in mobile phones to link the physical and the digital world. In Interactive Multimedia. Casablanca, Maroko: InTech.

WOLBER, D., ABELSON, H., SPERTUS, E., LOONEY, L. 2015. App Inventor 2, Create Your Own Android Apps. Inc. Sebastopol, USA: O'Reilly Media. 
Halaman ini sengaja dikosongkan 